\title{
International Standard on Auditing No. 260 and Audit Quality: Evidence from Jordan
}

\author{
Mohammad K. Shbeilat ${ }^{1}$ \\ ${ }^{1}$ Faculty of Business, Tafila Technical University, Jordan \\ Correspondence: Mohammad K. Shbeilat, Tafila Technical University, P. O. Box 179, Tafila 66110, Jordan.
}

Received: March 7, 2019

Accepted: March 12, $2019 \quad$ Online Published: March 13, 2019

doi:10.5539/ibr.v12n4p61

URL: https://doi.org/10.5539/ibr.v12n4p61

\begin{abstract}
This study aims to explore the extent of external auditors awareness of the requirements of the International Standard on Auditing No. 260 (Communications with those charged with governance) on audit quality and to shed light on the effectiveness of the communication process based on auditors actual experience. A mixed method approach was employed to achieve the study objectives. The analysis of 116 questionnaires concluded that the requirements of the ISA 260 enhance audit quality, but the two-way communication between Jordanian auditors and the audit committee is ineffective from external auditor's perception. The study also found that audit committees do not support external auditor when disagreements arise between auditors and their client management on accounting treatments. The qualitative interviews confirmed the quantitative results and revealed several explanations among which: 1) lack of qualified directors, 2) lack of a clear policy in selecting board members, 3) meetings with auditors are routinely held, and 4) insufficient oversight by the securities commission. The interviews also revealed that the recent version of Jordanian corporate governance has two potential factors have been viewed to improve the effectiveness of the communication process that are, the appointment of a 'governance liaison officer' who, among other responsibilities, supervise and document audit committee meetings with the auditor, and the use of cumulative voting technique in selecting board members. The findings of the study could be beneficial for regulators by ensuring the best implementation of cumulative voting to increase the representation of qualified members so that the communication process will be greatly enhanced.
\end{abstract}

Keywords: audit committees, audit quality, international standard on auditing 260, corporate communications, corporate governance

\section{Introduction}

The recent version of the International Standard on Auditing No. 260 (Communications with those charged with governance) became valid for periods ending on or after December 15, 2016. The ISA 260 "deals with the auditor's responsibility to communicate with those charged with governance in an audit of financial statements ... and identifies some specific matters to be communicated with them" (ISA 260, 2016, para.1 \& 2). Therefore, in order to ensure the highest level of effective communication between auditors and those charged with the company governance, it is important that members of board and the audit committee have sufficient knowledge about the applications of the IFRS because qualified audit committees are viewed as integral to the audit process and provide a great contribution to audit quality (CPAB, 2013).

Greedy and selfish executives prioritize their personal interests over company's goals using creative accounting techniques, where elected external auditors are supposed to resist management pressure to align the outcomes of the financial reporting to their favor. Hence, potential disagreements between independent auditor and the company management arise especially on difficult, subjective, and complex accounting policies and estimates. Complexities in accounting practices, derivatives and the choices between different alternatives of measurement policies, such as the fair value evaluation (Shbeilat \& Al-Harasees, 2018), give managers a wide room to manipulate accounting records and to manage earnings and profits as they wish. Goodwin (2002), among others argued that "an auditor who is concerned that a client may be lost ... succumbing to pressure to accept the client's position. However, from a professional point of view, this would be regarded as a compromise of independence." ( $p$. 384). Accordingly, much responsibilities have been placed on the vital role of the independent auditor, as the shareholder's agent, in securing financial reporting system (Rahim, Johari, \& Takril, 2015). 
External auditors who maintain effective communications with a powerful audit committee, play a significant role in mitigating "earning management" (Miko \& Kamardin, 2015; Piot \& Janin, 2007; Baxter \& Cotter, 2009; Chung et al 2005). External auditors may face pressure from the company management to issue favorable opinion. While auditors may opt to modify their opinions in case of disagreements with the company management, they must and required to communicate with those charged with the company governance all key audit matters during engagement period according to the ISA. 260 (Altawalbeh \& Alhajaya, 2019).

Jordan was an early reformer in terms of adopting accounting standards, auditing standards, and corporate governance initiatives in the region (Obaidat, 2007; Shehata, 2015; Al-Frijat, 2016). Obaidat (2007) investigated Jordanian auditors' compliance with the ISAs. A questionnaire was designed by listing all auditing standards and sought auditors' views about the extent of their compliance with the standards. The study showed that external auditors in Jordan comply with the ISAs with some statistical variance among the standards. Accordingly, the researcher arranged the standards according to the degree of compliance. Standard 260 (Communication of audit matters with those charged with governance) gained the 25th rank among the 32 standards. Therefore, this study seeks to answer the following research questions:

1- To what extent auditors are aware of the importance of the requirements of ISA 260 (Communication with Those Charged with Governance) in improving audit quality?

2- How effective is the communication process between external auditors and those charged with governance from external auditor's experience?

The study extends the auditor-audit committee communication literature by examining whether the audit committee plays a vital role in resolving disputes with the company executives. The current study also aims to fill the gap of the existent literature by providing evidences about how external auditors communicate with those charged with governance. Given the lack of publicly available qualitative articles and resources on the study topic, this study employed a mixed method approach to bridge the methodological gap in this area of studies. The expected contributions are: (1) Identify the approach applied by auditors in determining "those charged with governance" to communicate with (2) Identify possible strengths and weaknesses of effective communication process, (3) Identify the extent to which audit committees intervene in resolving disputes between auditors and the company management.

\section{Literature Review}

\subsection{Audit Quality}

Audit quality literature have identified several determinants of audit quality such as compliance with international standards on auditing, industry knowledge, audit committee effectiveness, auditor's independence, the provision of non-audit services, audit tenure, corporate accountability, audit firm size, and audit firm reputation (Ghafrana \& O'Sullivan 2017; Carcello et al, 1992; Zgarni et al, 2016; DeAngelo, 1981; Amahalu et al, 2018; Suyono, 2012; Al-Khaddash et al, 2013). Several studies with different methods were conducted to measure determinants of the audit quality, however, none of the previous studies succeeded in introducing a generally accepted definition of the audit quality (Montenegro \& Brás 2018; Knechel et al, 2013; Beattie et al, 2013).

Finding the right definition of the study variables not just helps in conducting the study, it also ensure gaining more accurate results. Due to the lack of a universally accepted definition of the audit quality, the majority of audit quality researches tend to have quantitative archival approach to provide more factual results (Beattie et al, 2013). However, Beattie et al, (2013) mentioned two drawbacks of quantitative archival empirical research, (1) it does not provide a clear causal relationship between the study variables and (2) the difficulty of finding the appropriate variables as a proxy for audit quality which may also expose the study to the 'risk of omitted variables', therefore they developed a questionnaire of 36 factors derived from the UK regulations to investigate their impact on audit quality post-SOX enactment, the study adopted the definition of the FRC (2006), and the main conclusion obtained from perceptions of CFOs, audit committee chairs, and external auditors showed that effective audit committee communications with external auditors is among the most prominent factors enhancing audit quality.

The current study adopts the definition provided by the Audit Inspection Unit (AIU) of the UK Financial Reporting Council (FRC). They referred to the concept of audit quality as:

"involves obtaining sufficient and appropriate audit evidence to support the conclusions on which the audit report is based and making objective and appropriate audit judgments. ... A quality audit [also] involves appropriate and complete reporting by the auditors which enables the Audit Committee and 


\section{Board properly to discharge their responsibilities". (FRC, 2006, p. 38).}

This definition was adopted for both the survey and the interviews. Reasons for this adoptions are: firstly, it comes from a highly regarded institution that carries out annual inspections at the UK audit firms to ensure highest level of audit quality (including the big four), secondly, the definition focuses on the outcome of the audit, the audit performance and the role of those charged with governance on audit quality, and therefore, this definition better serves the objectives of this study.

\subsection{Those Charged with Governance}

ISA 260 requires external auditors to determine the appropriate members within the entity's governance structure to communicate with taking into consideration the variance of company size and board structure in some jurisdictions. The standard, typically, considers the full board of directors (including executives in case they are members of the board) and the audit committees as the appropriate body to communicate with. For instance, in the USA, there are two sets of auditing standards, the first one issued by the Association of International Certified Professional Accountants (AICPA) which is applicable for the US private companies, and the other one issued by the Public Company Accounting Oversight Board (PCAOB) which is applicable for public shareholding companies and dealers (Arens et al., 2017). The AICPA standard SAS No. 114 "The Auditor's Communication With Those Charged With Governance" superseded SAS 61 "Communication with Audit Committees", the purpose of rewording the title of the standard from the audit committee to those charged with governance is to highlight auditor's responsibility of communicating with those who have the ultimate responsibility of overseeing entity's activity and to increase the scope of the communication process (Sertima, 2008), while the PCAOB's version of the same standard still indicates the audit committee as the governing body that auditors should communicate with. Internationally, the International Standard on Auditing 260, "Communication With Those Charged With Governance" require auditors to identify appropriate individuals to communicate with, in case the auditor decide to communicate with a subgroup of the board, such as the audit committee, the auditor must ensure that communications with this subgroup is sufficient and effective (ISA 260, para $11 \& 12$ ).

Apart from auditing standards, internationally recognized corporate governance frameworks and even those for developing countries rest the task of external auditor's communications with the audit committees, see for example (UK Corporate Governance Code, the Australian Corporate Governance Principles, the US SOX, Canadian Corporate Governance Codes and Principles, the Jordanian Instructions of Corporate Governance). This study uses both terms, i.e. "those charged with governance" and the "audit committees" as the body in charged with communications with external auditors. The reason is that external auditors are familiar with communicating with the audit committee since they are legally required to communicate with them, as mentioned in section 3.2, this study targets perceptions of auditors who audit listed companies, which are legally required to form audit committees.

\subsection{Communicating about Technical Disputes with the Company Management}

Several previous studies have affirmed the vital role of audit committees in supporting external auditor especially when disagreements arise between auditors and their client management on accounting policies, estimates and the appropriate application of accounting standards (Park 2018; Brown \& Popova 2015; Ng \& Tan 2003; Knapp 1985; Knapp 1987; Stewart \& Munro 2007; Brown-Liburd et al, 2016; Goodwin-Stewart \& Kent 2006; Salleh \& Stewart 2012)

Two early prominent empirical studies investigated auditor's ability to resist management pressure when technical disputes arise conducted by Knapp (1985) \& (1978). Knapp (1985) employed a full-factorial experiment using repeated measures technique and developed an experimental questionnaire of 16 randomly-ordered cases distributed to senior loan officers in the USA and sought their perceptions on factors affecting auditor's ability to resist management pressure. The study concluded that the outcome of conflicts tends to be in client's favor for companies with good financial condition and when the nature of the conflict is not dealt with precisely by the accounting standards. It is worth mentioning that Knapp's (1985) study has not addressed the role of the audit committee communications with auditors, however, two years later, with the same methodology, Knapp (1987) investigated factors affecting audit committee members in supporting external auditors when a disagreements arise during the audit engagement. The results of 179 experimental questionnaire distributed to audit committee members showed that audit committees do support auditors in disputes with the company management. The major factors that increase the likelihood of audit committee support are: member's background as an officer of other listed companies, the degree of objectivity of the issue according to accounting standards, and when the financial position of the company is weak. Interestingly, the latter finding implies a 
possible explanation of Knapp's (1985) finding that the outcome of conflicts tends to be in auditor's favor for companies with weak financial condition due to the intervention of the audit committee.

Another experimental evidence from Australia, found that effective communications, based on frequent meetings, between auditor and audit committee improves audit quality and reduces audit risks, the study also pointed out that audit committee assistance in resolving disputes also enhances audit quality (Stewart \& Munro 2007). Further $2 \times 2$ between-subjects experiment study conducted by Brown and Popova (2015) to investigate the interaction of 'management incentives' and 'audit committee communication on auditor judgment', revealed that with a higher executive incentives the audit committee communication with auditors play significant role in enhancing audit quality in terms of accumulating and evaluating sufficient and appropriate audit evidences.

In the same context, another experimental studies sought perceptions of CFOs about executive techniques in affecting audit negotiation showed that effective communication between audit committees and auditors lessens management pressure on auditors and mitigate management's use of the personal relationship with the auditor that result from the length of the audit period (Brown-Liburd et al, 2016; Brown-Liburd \& Wright, 2011) and also pointed out that strong audit committee make the company management less aggressive in negotiating audit judgments. Further experimental finding by Hatfield et al (2011) suggested that a higher management pressure reduces auditor's proposals of necessary accounting adjustments, thus, the need for effective communication with the audit committee is necessary to support the auditor's position.

A quantitative study in Australia by Goodwin-Stewart \& Kent (2006) found that effective communications between powerful audit committees and auditors result in higher audit fee confirming the argument that audit committee's support motivates auditors to exercise a higher level of assurance. A qualitative evidence from Malaysia resulted from interviewing audit committee members, external auditor and CFOs revealed that audit committees play a mediator role in resolving material technical issues between auditors and managers (Salleh \& Stewart 2012). Finally, Park (2018) developed two regression models based on data obtained from the Korean stock market and concluded that the presence of strong audit committee, together with the compliance with effective audit committee charter mitigates management pressure on auditor's related decisions and enhances audit quality.

\section{Method}

\subsection{Mixed Method}

To achieve the objectives of the study and to answer the study research questions, a mixed method approach was employed for this study. The parallel mixed method approach is the technique utilized for this study; this means that data collection and analysis for both the quantitative and the qualitative method will be conducted concurrently. The use of multiple methods produces robust findings by combining the advantages of both methods and by neutralizing some of the deficiencies of certain method (Jick, 1979), and "turns possible to overcome the limitations of quantitative and qualitative methodologies, allowing the researcher to get rich information that could not be obtained using each method alone" (Almeida, 2018, p. 137). The mixed method also increases the generalizability of the study outcomes, provides comprehensive vision of the phenomena being studied, and helps in obtaining sufficient insights for better interpreting participants' perceptions (Bazeley, 2015; Greene \& Caracelli, 1997; Plastow, 2016; Borkan, 2004; Tashakkori \& Teddlie, 2010).

Finally, meeting the study objectives and answering its questions are better achieved in mixed methods (Bazeley, 2015). "Using a mixed method approach provides the best opportunity for addressing research questions" (Malina et al, 2011 p. 60). Therefore, since the study research questions might not be addressed properly using one approach alone, the mixed method is a better choice for this study; for instance, the quantitative approach can answer the first study research question (RQ.1) properly, but cannot do the same for the second research question (RQ.2) and vice versa.

RQ.2 mainly aims at exploring how effective is the communication process between the auditors and those charged with governance from auditors own experience?, an in-depth interview can bring closer insights about potential factors that may affect the effectiveness of the communication process, especially with the help of the follow-up questions. While exploring the impact of the application of the International Standard on Auditing No. 260 on audit quality (RQ.1) can be properly answered using the quantitative approach, however, mixing the two approaches also helps in increasing the generalizability of the study findings. The final step is integrating the mixed methods outcomes to facilitate interpreting the findings of each other and to help infer conclusions.

As mentioned earlier in section (2.1), this study adopted the definition provided by the UK Financial Reporting Council (FRC) for both the survey and the interviews. 


\subsection{Research Instrument \& Interview Protocol}

Both the questionnaire statements and the interview questions were developed from the requirements of ISA 260, the recent version of the Jordanian corporate governance instructions of 2017, and from the related literature. The respondents were informed about the objectives of the study, the requirements of the ISA 260 and the adopted definition of audit quality.

The first draft of both the questionnaire and the interview protocol were sent to three academicians in auditing and three external auditors. Minor comments were received and considered for the final versions. The first section of questionnaire requests demographic background focusing on their experience as external auditors, the gender and their position in the audit firm. Section B presents questionnaire statements to examine the impact of the requirements of the International Standard on Auditing No. 260 on audit quality and to investigate possible strengths and weaknesses that may affect the effectiveness of the communication process between auditors and those charged with the company governance. Respondents are required to indicate their opinion based on the five-scale Likert measurement that ranges from Strongly Disagree to strongly agree as following:

(5 - Strongly agree), (4 - agree), (3 - neutral), (2-disagree), (1 - strongly disagree).

In conjunction with the quantitative approach, 10 interviews were conducted with external auditors to investigate their viewpoints about the effects of the requirements of ISA 260 on improving audit quality and to investigate the effectiveness of communications process between auditors and those charged with governance, further, the interviews sought to explore strengths and weaknesses that affect the effectiveness of the communication. The interviews were pre-arranged by telephone and the duration of the interviews lasted from 37 to 48 minutes.

Main questions asked to participants during the interviews are:

- According to the requirements of ISA 260 who are the persons or committees within the entity's governance structure that you consider appropriate to communicate with?

- How does your assessments of the requirements of ISA 260 (Communication with Those Charged with Governance) affect your perception in improving audit quality?

- How effective is the actual communication process between external auditors and those charged with governance based on your own experience in practice?

- Do audit committees support you in case a disagreement arises between you and the executive management on the appropriate application of accounting standards?

- What are the possible strengths and weaknesses that may affect the effectiveness of the communication process?

Furthermore, several follow-up questions were asked to get deeper insights from respondents to serve the purpose of the study

\subsection{The Study Unit of Analysis}

The study unit of analysis for both the questionnaires and interviews are external auditors who have had experience in auditing listed companies. The choice of external auditors as the study sample is because the Jordanian corporate governance instructions as well as all international corporate governance require external auditors to communicate all matters related to auditing and financial reporting with the audit committee, therefore external auditors were seen as the most appropriate study sample to answer the study questions.

According to the website of Jordanian Association of Certified Public Accountants the number of licensed and audit practitioners is 415 (Accessed on August 2, 2018). The study sample was derived based on the formula of Mason, Gunst, \& Hess, (2003) as following:

The study population / [1+ (study population * study' moral level square)]. Therefore, the study sample is $=415$ / $(1+(415 * 0.0025))=203$. This, however, also corresponds to a very high degree with the suggested table of "sample size for a given population size" by Sekaran's (2003, p. 294). Early July 2018, 203 questionnaires were distributed randomly to the targeted external auditors. 116 usable responses were received giving a response rate of $57 \%$.

\section{Findings and Discussion}

\subsection{Quantitative Results \& Discussions}

Table 1 presents the practical experience of the respondents as a licensed certified public accountant, it can be seen from the table 1 that the average of respondent's experience in auditing is around Ten years. The other 
classification of respondents is their position in the audit firm; $37 \%$ Junior \& semi-senior auditor, 52\% senior auditor, $10 \%$ Manager and $1 \%$ partner. With 10 years average of experience as licensed auditor and a large number of positions higher than "junior" the viewpoints of respondents are, arguably, considered adequate to achieve the objectives of this study.

Table 1. Participant's Experience as a licensed auditor

\begin{tabular}{lc}
\hline Statistics & Experience as a licensed auditor (Years) \\
\hline Average & 9.73 \\
Median & 9 \\
Minimum & 5 \\
Maximum & 18 \\
\hline
\end{tabular}

Table 2 and part of the interview questions addresses research question 1. Table 2 indicates that means of sample subjects' responses that measure the importance of the requirements of ISA 260 on improving audit quality ranged between (3.75 -4.54) with standard deviations (1.338 and .638) respectively. In this study, three ranks are used that are "high", "medium or moderate" and "low" with an interval of 1.33 between the ranks. The results indicate high degrees of sample's agreement. The general mean $=4.041$ also confirms that Jordanian external auditors are aware of the importance of the requirements of ISA 260 (Communication with Those Charged with Governance) on improving audit quality. The table also shows that statement number 12 "Communicating outstanding significant matters, that haven't been addressed by the company management, with those charged with governance" obtained the highest rank in improving audit quality. This, however, reflects a clear commitment by the auditors to the importance of communicating key audit matters to those charged with governance as required by auditing standards.

Table 2. Means, Standard deviations, Ranks and Degrees of sample responses regarding the importance of the requirements of ISA 260 on improving audit quality

\begin{tabular}{|c|c|c|c|c|c|}
\hline $\begin{array}{l}\text { Item } \\
\text { No. }\end{array}$ & Statements & Mean & $\begin{array}{l}\text { Standard } \\
\text { Deviation }\end{array}$ & Rank & Degree \\
\hline 1 & $\begin{array}{l}\text { Determining the appropriate members within the entity's } \\
\text { governance structure to communicate with }\end{array}$ & 3.75 & 1.338 & 21 & High \\
\hline 2 & $\begin{array}{l}\text { Communicating with independent non-executive persons within the } \\
\text { entity's governance structure }\end{array}$ & 3.94 & 1.218 & 15 & High \\
\hline 3 & $\begin{array}{l}\text { Identifying auditor's responsibilities, in relation to auditing } \\
\text { financial statement, with those charged with governance. }\end{array}$ & 4.16 & .966 & 6 & High \\
\hline 4 & $\begin{array}{l}\text { Identifying management's responsibilities, in the preparation of the } \\
\text { financial statement, with those charged with governance. }\end{array}$ & 4.01 & .716 & 12 & High \\
\hline 5 & $\begin{array}{l}\text { Identifying the responsibilities of those charged with governance in } \\
\text { overseeing the preparation of the financial statement. }\end{array}$ & 3.88 & 1.031 & 16 & High \\
\hline 6 & $\begin{array}{l}\text { Obtain information relevant to the audit from those charged with } \\
\text { governance. }\end{array}$ & 4.22 & .770 & 3 & High \\
\hline 7 & $\begin{array}{l}\text { Identifying scope and timing of the audit with those charged with } \\
\text { governance. }\end{array}$ & 3.97 & 1.318 & 13 & High \\
\hline 8 & $\begin{array}{l}\text { Communicating auditor's views about significant accounting } \\
\text { practices, policies, and estimates. }\end{array}$ & 4.38 & .718 & 2 & High \\
\hline 9 & $\begin{array}{l}\text { Communicating scope limitations in the audit with those charged } \\
\text { with governance. }\end{array}$ & 3.78 & 1.037 & 19 & High \\
\hline 10 & $\begin{array}{l}\text { Communicating significant difficulties encountered during the audit } \\
\text { with those charged with governance. }\end{array}$ & 3.85 & 1.073 & 17 & High \\
\hline
\end{tabular}


11 Communicating significant matters and circumstances that may require modifications to the standard audit report.

12 Communicating outstanding significant matters, that haven't been addressed by the company management, with those charged with governance.

13 Discussing management's response to the written auditor's observations with those charged with governance.

14 Communicating auditor's justifications about the appropriateness of accounting practices in conformity with IFRS from the auditor's professional judgment.

15 Discussing auditor's compliance with applicable ethical requirements regarding independence with those charged with governance.

16 Communicating, proportionality of audit fees with audit services provided, with those charged with governance.

17 Communicating justifications and proportionality of non-audit services fees with non-audit services provided, with those charged with governance.

18 Communicating auditor's safeguards and measures to mitigate or eliminate identified threats to independence, with those charged with governance.

19 Agreeing with those charged with governance on appropriate timing, content and nature of the communication (oral, written).

20 Auditor's evaluation of the efficiency of the communication process between the auditor and those charged with governance.

21 Documenting all two-way communication between the auditor and those charged with governance and retain them as part of the audit documentation (whether orally or in writing).
4.06

4.54

1.015

10

High

54

.638

1

High

4.13

1.220

8

High

3.96

$1.042 \quad 14$

High

3.77

1.274

20

High

4.16

1.223

7

High

4.0345

1.38269

11

High

3.7845

1.03677

18

High

4.1897

1.25049

4

High

4.1207

1.04802

9

High

4.1724

1.01532

5

High

\section{General Mean}

4.0411

.45808

High

For the purpose of confirming the above mentioned result, one - sample $\mathrm{T}$-Test was also made in table 3 shows the obtained results.

Table 3. Results of T- Test

\begin{tabular}{ccccc}
\hline Mean & Standard Deviation & Df & T - Calculated & Sig \\
\hline 4.04 & 0.458 & 115 & 24.497 & 0.000
\end{tabular}

Table (3) indicates that T- calculated value is significant at level (0.05). This means that there is an impact of the requirements of ISA 260 (Communication with Those Charged with Governance) in improving audit quality from external auditor's perception. Finally the Cronbach's alpha was computed to test the the reliability of the study instrument. The value of Cronbach's alpha of the above instrument statements is 0.897 which is higher than the accepted percentage value of (0.70) as indicated by Saunders et al., (2012).

In regard to the second research question, table 4 shows that means of auditors' responses about the effectiveness of the communication process from their own past experience ranged between (1.76 -3.89) with standard deviations (1.381 and 1.369) respectively. The results show different degrees of sample's agreements. The vast majority responses are medium degrees indicating that external auditors perceive that the degree of effectiveness of the communication process with the audit committees is moderate. The Table also shows that statement no. (9) "The audit committee conduct at least one meeting with the external auditor without the presence of the company management" is the only statement with a high degree and ranked the first. The explanation of this high degree is that this kind of meeting is a mandatory requirement of the Jordanian corporate governance. On the other hand, statement no. (10) "Audit committees support external auditor when disagreements arise between 
the auditor and their client management on accounting policies, estimates and the appropriate application of accounting standards" ranked the last one. The general mean $=3.0973$ confirms that Jordanian external auditors perceive that the degree of the effectiveness of the communication process between them and the audit committee is moderate.

Table 4. Means, Standard deviations, Ranks and Degrees of sample responses regarding the degree of the effectiveness of the communication process from their own past experience

\begin{tabular}{|c|c|c|c|c|c|}
\hline $\begin{array}{l}\text { Item } \\
\text { No. }\end{array}$ & Statements & Mean & $\begin{array}{l}\text { Standard } \\
\text { Deviation }\end{array}$ & Rank & Degree \\
\hline 1 & $\begin{array}{l}\text { The audit committee discusses all matters related to } \\
\text { the nomination of the company external auditors. }\end{array}$ & 2.98 & 1.620 & 11 & Moderate \\
\hline 2 & $\begin{array}{l}\text { Audit committees discuss decisions regarding } \\
\text { external auditor's retention. }\end{array}$ & 3.35 & 1.638 & 8 & Moderate \\
\hline 3 & $\begin{array}{l}\text { Audit committees discuss decisions regarding } \\
\text { external auditor's dismissal. }\end{array}$ & 3.39 & 1.570 & 7 & Moderate \\
\hline 4 & $\begin{array}{l}\text { Audit committees discuss all decisions regarding the } \\
\text { determination of external auditor's fees. }\end{array}$ & 3.28 & 1.388 & 9 & Moderate \\
\hline 5 & $\begin{array}{l}\text { Audit committees pre- approve the provision of } \\
\text { non-audit services and related fees. }\end{array}$ & 1.93 & 1.597 & 12 & Low \\
\hline 6 & $\begin{array}{l}\text { Audit committees discuss the contents of the } \\
\text { engagement letter, in terms of auditor's plan, scope } \\
\text { and timing, with the external auditor }\end{array}$ & 1.91 & 1.547 & 13 & Low \\
\hline 7 & $\begin{array}{l}\text { External auditors have free access to meet audit } \\
\text { committee chair and members as necessary. }\end{array}$ & 3.67 & 1.733 & 2 & Moderate \\
\hline 8 & $\begin{array}{l}\text { Audit committee members possess necessary related } \\
\text { experience in accounting and are financially } \\
\text { qualified enough to effectively communicate with } \\
\text { external auditors. }\end{array}$ & 3.65 & 1.551 & 3 & Moderate \\
\hline 9 & $\begin{array}{l}\text { The audit committee conduct at least one meeting } \\
\text { with the external auditor without the presence of the } \\
\text { company management. }\end{array}$ & 3.89 & 1.369 & 1 & High \\
\hline 10 & $\begin{array}{l}\text { Audit committees support external auditor when } \\
\text { disagreements arise between the auditor and their } \\
\text { client management on accounting policies, estimates } \\
\text { and the appropriate application of accounting } \\
\text { standards. }\end{array}$ & 1.76 & 1.381 & 14 & Low \\
\hline 11 & $\begin{array}{l}\text { Audit committees discuss and consider external } \\
\text { auditor's suggestions and reservations regarding the } \\
\text { appropriate applications of the IFRS. }\end{array}$ & 3.42 & 1.561 & 5 & Moderate \\
\hline 12 & $\begin{array}{l}\text { The audit committee follows up the extent of } \\
\text { management's response to the external auditor's } \\
\text { reservations and report outstanding matters to the } \\
\text { board. }\end{array}$ & 3.46 & 1.585 & 4 & Moderate \\
\hline 13 & $\begin{array}{l}\text { The audit committee reviews and consider external } \\
\text { auditor's evaluation of the effectiveness of internal } \\
\text { control. }\end{array}$ & 3.40 & 1.673 & 6 & Moderate \\
\hline 14 & $\begin{array}{l}\text { The audit committee report to the board of directors } \\
\text { internal audit deficiencies based on external } \\
\text { auditor's evaluation. }\end{array}$ & 3.27 & 1.551 & 10 & Moderate \\
\hline & General Mean & 3.0973 & 1.13164 & & Moderate \\
\hline
\end{tabular}


For the purpose of confirming the above mentioned result, one - sample $\mathrm{T}$-Test was made, table (5) shows the obtained results.

Table 5. Results of T- Test

\begin{tabular}{ccccc}
\hline Mean & Standard Deviation & Df & T - Calculated & Sig \\
\hline 3.09 & 1.316 & 115 & 0.926 & 0.356 \\
\hline
\end{tabular}

Table (5) indicates that T- calculated value is not significant at level (0.05). This means that Jordanian external auditors perceive that the actual communication with the audit committee is ineffective. Finally the Cronbach's alpha was computed to test the reliability of the study instrument. The value of Cronbach's alpha is 0.858 which higher than the accepted percentage value of (0.70) as indicated by Saunders et al., (2012).

\subsection{Qualitative Results \& Discussions}

The qualitative interviews also revealed that external auditors are aware of the importance of the requirements of the ISA 260 (Communication with Those Charged with Governance) on improving audit quality (Research Question 1) confirming the quantitative findings as shown in table (2).

When they asked about the body within the entity's governance structure that they consider appropriate to communicate with, all responses referred to the audit committee.

The audit committee is responsible for all matters related to the work of external auditors. Corporate governance instruction clearly stated the roles of the audit committee in overseeing the work of external auditors. (Subject D)

An important theme emerged from their responses which has positively enhanced entity's compliance with corporate governance instruction is the new requirement of recent Jordanian corporate governance instruction to appoint a "Governance Liaison Officer", because the governance liaison officer coordinates with the Jordanian Securities Exchange regarding company's governance applications.

The governance liaison officer informed and reminded us that our meetings with the audit committee will be reported within the governance report of the company annual report. (Subject J)

In regard to the requirements of the ISA 260, all interviewees affirmed its importance in improving audit quality. This, however, could be explained due to the fact that compliance with the international standards on auditing in Jordan is legal binding for auditors. Respondents revealed that adherence to the requirements of ISAs in general and ISA 260 in particular not only serves audit quality, it also serves the auditors by communicating their responsibilities to those charged with governance. Therefore, they maintain and document all supporting audit evidences and correspondences with both the company executives and those charged with governance.

Auditors must document and communicate all significant and key audit matters with the audit committee and the board of directors in order to discharge their responsibility and liabilities towards the shareholders. (Subject I)

The new revision of the ISA (700) and ISA (701) require auditors to communicate key audit matters with those charged with governance. This enhances audit quality because outstanding audit matters will be followed up by the board and the audit committee. (Subject $A$ )

Subjects B,E, F and J raised the point of the of the role of the Jordanian Securities Commission in following up auditor's reservations especially those include doubts about entity's ability to continue as a going concern in the audit report.

The Jordanian Securities Commission request listed companies to address auditor's reservations in order not to suspend their shares from trading (Subject F).

In regard to Research Question (2), the qualitative interviews showed that external auditors perceive that the actual communication process between them and the audit committees, is ineffective which also confirms the quantitative findings as shown in table (4). The Interviews shed lights and provided more insights about the actual communication process. Furthermore, the interviews revealed some important themes emerged from external auditors comments. Table (6) shows the thematic frequency analysis regarding the second research question. 
Table 6. Analysis of external auditor's comments regarding the effectiveness of the communication process from their actual experience

\begin{tabular}{lcc}
\hline Key Themes Emerged from External Auditors' Reponses & Frequency & Percentage \\
\hline $\begin{array}{l}\text { Board qualification is not an important factor for selection. Many members } \\
\text { appointed because they were public figures, relatives and/or friends. }\end{array}$ & 10 & $100 \%$ \\
$\begin{array}{l}\text { The dominance of family businesses in Jordan on the board of directors and } \\
\text { executive positions }\end{array}$ & 8 & $80 \%$ \\
Cumulative voting. & 6 & $70 \%$ \\
Number and agenda of meetings. & $60 \%$ \\
Insufficient oversight by the securities commission. & 6 & $60 \%$ \\
\hline
\end{tabular}

The most frequent remarkably theme as shown in Table 6 was the qualifications of the board of directors and the presence of personal reasons for the selecting board members. In fact, there is consensus among auditors that they do not get support from the audit committees when a dispute arise with the company management on accounting treatment and policies. They attributed this, mainly to the weak audit committee's qualifications and experience in the IFRS. A noteworthy comment by subject $\mathrm{J}$ means that how can incompetent member in accounting argue and defend his propositions before external auditors.

Who does not have thing cannot give it. (Subject J).

Subject B pointed out that some listed companies select ex-prime ministers, ex ministers, ex-MPs within the board of directors because of friendship relations or because they are from the same political party regardless of their eligibility to perform their duties as a governance and oversight body. Subject J also criticized the culture of appointing well-known public figures for the purpose of facilitating the company operations through their personal relationships rather than their qualifications and technical skills.

Subject $\mathrm{H}$ suggested that if, at least one of the audit committee members possess a CPA certificate, then the two-way communication will be much effective and productive, where Subject I stressed that audit committee members should only possess an accounting degree with a minimum of 5 years of experience in accounting (not a degree or experience in other discipline even if they are related disciplines)

There is no real oversight by the securities commission and the other regulating authorities on the qualifications of the members of the audit committees in terms of experience in the preparation of the financial statements, audit and accounting matters. (Subject $C$ ).

The securities commission and the JA-CPA must ensure that external auditors' nomination, retention and fees are determined by a truly independent audit committees, not the CEO. Otherwise, there will be no incremental enhancements to the audit performance. (Subject B).

The Jordanian governance code were concerned with meeting the minimum requirements of independence conditions when selecting the board members, and to meet the minimum requirements of qualification and experience. However, it failed to emphasize interest in other matters such as the actual experience in understanding and applying the international accounting standards.

Comments about the large proportion of the family controlled companies, which characterizes Jordanian capital markets (AlQatamin, 2018b) took a wide room of participant's discussion. The participants revealed that in some cases they did not feel the distinction between a board member and executive member especially in companies run by a mix of relatives and family members.

While discussing a non-audit service matter with an audit committee member, he asked me to check with the CEO first. (Subject F).

While Subject G pointed out that discussing the provision of some non-audit services with the company managers especially the $\mathrm{CFO}$ and the $\mathrm{CEO}$ reflects the extent to which the executive managers are overriding the powers of the audit committees.

The nature of family business in Jordan, somehow, removes the barriers between executives and non-executives members. (Subject $C$ )

However, Subjects A, C, D, E and H pointed that in family business model you feel that both the board and the 
company executives work like a one team, although the board has an oversight role where the managers have an executive and administrative roles. However, Subject A added that the advantage here is the workflow proceeds smoothly when there is no conflicts, but in the case of conflicts and disagreements on accounting or auditing matter we expect no support from the audit committee nor the board.

The nature of appointing board members was heavily criticized by interviewees in comments about possible future enhancements to increase the diversity and the competence of those charged with governance. Some interviewees hope that the cumulative voting, which is supposed to become mandatory this financial year (2019) will play a role in the existence of new blood within the Board of Directors' composition.

Cumulative voting expands board diversity and gives small shareholders better chance to represent themselves in the board and oversee the company, this will increase the effectiveness of the board's communication with the auditors as well as the shareholders. (Subject D).

Cumulative voting may reduce the dominance of the major shareholders in overriding audit committee decisions, especially those related to the work of the external auditor. (Subject A)

We hope that cumulative voting will reduce or limit the presence of members who care about their common interests at the expense of the company's interests. (Subject F)

External auditor meetings with the audit committees were criticized by subjects B, C, F, G and I. Subject B \& I pointed out that number of meetings is insufficient, and also added, together with subjects $\mathrm{C}, \mathrm{F} \& \mathrm{G}$ that poor agenda and unqualified members reduces the effectiveness the meetings and the communication process. In addition to that Subject $\mathrm{F}$ went further by stating that he gets permission to perform non-audit services from the CEO (not the audit committee), then, however, he gets a formal approval from the chairman of the audit committee who agrees upon the approval of the CEO. Subjects C, G \& I mentioned that the recent instructions of the Jordanian corporate governance gave the audit committees the right to report any dispute between their decisions and the decisions of the board of directors in the annual report

Board members who were former ministers must change their mentality during their meeting with us, that the public administration is completely different from the private sector (Subject I)

\begin{abstract}
Subject B
"We conduct only one meeting with the audit committee without the presence of executives to meet the requirements of corporate governance, even if there is no actual agenda of meeting to discuss".

Interviewer: "corporate governance requires at least one meeting, which means that several meetings could be conducted with the audit committee. Have you ever requested meetings with the audit committee to discuss matters related to accounting or auditing?"

Subject: "to my knowledge, we did not ask audit committees to hold any meetings"

Interviewer: could you please explain why?

Subject: the reason is we solve matters regarding the proper implementation of the IFRS with the CEO, and in some other complex cases we communicate the chairman of the board"
\end{abstract}

\title{
5. Conclusions \& Discussion
}

This paper investigated the effectiveness external auditor's communication with audit committees and its impact on audit quality. The study main results show that external auditors are aware of the importance of the requirements of the ISA 260 (communications with those charged with governance) in improving audit quality (Research question 1). However, both the quantitative and qualitative results suggested that the communication process was ineffective (Research question 2).

The finding of this study consistent with Obaidat (2007) who found that Jordanian external auditors comply with the ISAs and aware of their importance on audit quality. Although Obaidat's study showed that ISA 260 gained a low rank of compliance, in comparison with the other standards, this however, could be explained to the fact that his study was conducted before the establishment of the first version of the Jordanian corporate governance code for public shareholding companies in 2009 , which has vested the audit committee a significant role in facilitating the work of the external auditors and organized the mechanism of the communication between auditors and the company. Another possible explanation is that time several Arabic translation for the term corporate governance were emerged in Jordan which might distracted their understanding of the term corporate governance (Shbeilat, 2013). The results also consistent with Beattie et al. (2013) who investigated factors affecting audit quality in the 
UK, and found the factor "Auditor required to communicate with the audit committee on all key issues associated with the audit, and with ethical standards" (p. 67) the most factor enhancing audit quality. A possible explanation, based on the interviewees' comments, is the recent enhancements of the new instructions of the Jordanian corporate governance (version 2017) which mandated listed companies to appoint 'governance liaison officer' who supervise and document audit committee meetings with the auditor. Alqatamin (2018a) found that audit committee independence has positive relation with company performance in Jordan while number of audit committee meetings has no association, this, however, this could be attributed to the panel regression method of Alqatamin's study which links the number of audit committee meetings with the (ROA) regardless of the efficiency of the meetings which has been heavily criticized by the interviewees of this study.

The main quantitative finding of this study suggests that audit committees do not support external auditor when disagreements arise between auditors and their client management on accounting policies, estimates and the appropriate application of accounting standards. The qualitative interviews have strongly affirmed this suggestion and attributed that to the dominance of family members and friends over the board and the upper management regardless of their qualifications and technical experience in accounting and the IFRS. The results also consistent with Abdullatif et al, (2015) and Abdullatif (2006) who found that audit committees in Jordan perform their duties and responsibilities to a moderate level. Abdullatif et al, (2015) attributed their findings to the existence of a large portion family controlled businesses in Jordan, which, accordingly reduces the need for effective audit committees. This, however, consistent with the viewpoints of the interviewees who pointed out that in many family companies the executives override the roles of audit committee's decisions regarding auditor's work. Interestingly, the interviews revealed a positive impact of management's control over audit committee decisions, that is audit procedures are conducted smoothly especially when the company has a qualified financial manager and a team of competent accountants, and vice versa. This also appears to be a strong affirmation to the argument that family business model tends to have low agency conflicts due to the overlap between the company directors, managers and the owners (Songini \& Gnan, 2015).

\section{Research Implications}

The results of this study are of relevance to regulators and the Jordanian associations of certified public accountants in evaluating the effectiveness of the two-way communication between external auditors and those charged with governance. The interviews also revealed several factors that have negatively affected the effectiveness of the communication between auditors and those charged with governance such as: appointing public figures and relatives regardless of their eligibility, insufficient oversight by the securities commission, and the routine meetings of audit committee members without properly prepared agenda.

On the other hand, the interviews showed two potential factors have been viewed to improve the effectiveness of the communication process and thus, improve audit quality, that are the appointment of a 'governance liaison officer' and the new method of selecting the board members which is the cumulative voting. These factors are also of relevance to the Jordanian securities commission and the company control department which are in charge of overseeing entity's compliance with the instructions of corporate governance. Regulators must ensure the best implementation of cumulative voting during the general assembly meetings. It is hoped that cumulative voting will positively increase the representation of qualified, non-executive and independent members so that the communication process will be greatly enhanced. Further, the findings should be of interest to academicians to explore the impact of the enhancements added to the recent version of corporate governance in Jordan. Since the current year (2019) is the first year of the mandatory application of cumulative voting. Future researches are encouraged to investigate its effects on (1) producing strong and diversified board and audit committee members and (2) the extent of the representation of the minority shareholders in improving the performance of those charged with entity governance and the communication process with external auditors. Finally, cautions must be considered for the purpose generalizing the findings of this study because it reflects Jordanian's unique culture in an emerging capital market such as the appointment of public figures who were previously worked in the public sectors as prime ministers, ministers which is totally differ from running the private sector.

\section{References}

Abdullatif, M., Ghanayem, H., Ahmad-Amin, R., Al-Shelleh, S., Sharaiha, L. (2015). The performance of audit committees in Jordanian public listed companies. Corporate Ownership \& Control, 13(1-10), 1122-1133. https://doi.org/10.22495/cocv13i1c10p1

Abdullatif, M. (2006). The Effectiveness of Audit Committees in Jordanian Public Shareholding Companies and Potential Company Characteristics Affecting It: Perceptions from Auditors in Jordan. Dirasat, Administrative Sciences, 33(2), 450-468. 
Al-Frijat, Y. (2016). The Dynamics Application of Accounting Standards, and Its Importance in the Measurement with Fair Value \& Disclosure, Asian Journal of Finance \& Accounting, 8(2), 46-59. https://doi.org/10.5296/ajfa.v8i2.9354

Al-Khaddash, H., Al Nawas, R., \& Ramadan, A. (2013). Factors affecting the quality of Auditing: The Case of Jordanian Commercial Banks. International Journal of Business and Social Science, 4(11), 206-222

Almeida, F. (2018). Strategies to perform a mixed method study. European Journal of Education Studies, 5(1), 137-151.

AlQatamin, R. (2018a). Audit Committee Effectiveness and Company Performance: Evidence from Jordan, Accounting and Finance Research, 7(2), 48-60. https://doi.org/10.5430/afr.v7n2p48

AlQatamin, R. (2018b). Do Family-Owned Companies Achieve High or Low Performance? Evidence from Jordan, International Journal of Academic Research in Accounting, Finance and Management Sciences, $8(1), 215-223$.

Altawalbeh, M., \& Alhajaya, M. (2019) The Investors Reaction to the Disclosure of Key Audit Matters: Empirical Evidence from Jordan, International Business Research, 12(3). https://doi.org/10.5539/ibr.v12n3p50

Amahalu, N., Okeke, M., \& Obi, J. (2018). Audit Quality Determinants: Evidence from Quoted Health Care Firms in Nigeria, International Journal of Academic Research in Accounting, Finance and Management Sciences, 7(4), 216-231.

Arens, A., Elder, R., Beasley, M., \& Hogan, C. (2017). Auditing and Assurance Services, Global Edition, 16/E.

Baxter, P., \& Cotter, J. (2009). Audit committees and earnings quality, Accounting and Finance, 49(2), 267-290. https://doi.org/10.1111/j.1467-629X.2008.00290.x

Bazeley, P. (2015). Mixed Methods in Management Research: Implications for the Field. The Electronic Journal of Business Research Methods, 13(1), 27-35. Retrieved June 12, 2018 from http://www.ejbrm.com/issue/download.html?idArticle=396

Beattie, V., Fearnley, S., \& Hines, T. (2013). Perceptions of Factors Affecting Audit Quality in the Post-SOX UK Regulatory Environment, Accounting \& Business Research, 43(1), 56-81. https://doi.org/10.1080/00014788.2012.703079

Borkan, J. M. (2004). Mixed Methods Studies: A Foundation for Primary Care Research. Annals of Family Medicine, 2(1), 4-6. https://doi.org/10.1370/afm.111

Brown, J., \& Popova, V. (2015). The Interplay of Management Incentives and Audit Committee Communication on Auditor Judgment, Behavioral Research in Accounting: Spring, 28(1), 27-40. https://doi.org/10.2308/bria-51259

Brown-Liburd, H., \& Wright, A. (2011). The Effect of Past Client Relationship and Strength of the Audit Committee on Auditor Negotiations. AUDITING: A Journal of Practice \& Theory: 30(4), 51-69. https://doi.org/10.2308/ajpt-10143

Brown-Liburd, H., Wright, A., \& Zamora, V. (2016) Managers' Strategic Reporting Judgments in Audit Negotiations. AUDITING: A Journal of Practice \& Theory: February 35(1), 47-64. https://doi.org/10.2308/ajpt-51306

Carcello, J. V., Hermanson, H., \& McGrath, H. T. (1992). Audit quality attributes: the perception of audit partners, preparers and financial statement users. Auditing: a journal of practice and theory, 11(1), 1-15.

Chung, R., Firth, M., \& Kim, J. (2005). Earnings management, surplus free cash flow and external monitoring, Journal of Business Research, 58(6), 766-776. https://doi.org/10.1016/j.jbusres.2003.12.002

CPAB. (2013). Oversight of the external auditor: Guidance for audit committees, Canadian Public Accountability Board (CPAB). Retrieved June 5, 2018, from https://www.cpacanada.ca/en/business-and-accounting-resources/audit-and-assurance/enhancing-audit-quali ty/publications/external-auditor-oversight-audit-committee-guidance

DeAngelo, L. E. (1981). Auditor size and audit quality. Journal of accounting and economics, 3(3), 93-199. https://doi.org/10.1016/0165-4101(81)90002-1

FRC. (2006). Audit Inspection Unit, 2005/6 audit quality inspection, public report-July 2006, Retrieved April 20, 2018 from: 
https://www.frc.org.uk/getattachment/d2a434ea-a531-4fe8-b3c1-0ae0c7ab3ec3/AIU-Public-Report-2005-6. pdf

Ghafrana, C., \& O'Sullivan, N. (2017). The impact of audit committee expertise on audit quality: Evidence from UK audit fees, The British Accounting Review, 49(6), 578-593. https://doi.org/10.1016/j.bar.2017.09.008

Goodwin, J. (2002). Auditor' conflict management styles: An exploratory study. Abacus, 38(3), 378-405. https://doi.org/10.1111/1467-6281.00114

Goodwin-Stewart, J., \& Kent, P. (2006). Relation Between External Audit Fees, Audit Committee Characteristics and Internal Audit'. Accounting \& Finance, 46(3), 387-404.

https://doi.org/10.1111/j.1467-629X.2006.00174.X

Hatfield, R. C., Jackson, S. B., \& Vandervelde, S. D. (2011). The Effects of Prior Auditor Involvement and Client Pressure on Proposed Audit Adjustments. Behavioral Research in Accounting 23(2), 117-130. https://doi.org/10.2308/bria-10064

ISA 260. (2016). Communication with those charged with governance, International Standards on Auditing ISA 260 issued by the IAASB of the IFAC, Retrieved January 17, 2018, from https://www.ifac.org/publications-resources/international-standard-auditing-isa-260-revised-communication -those-charged-g

Greene, J. C., Caracelli, V. J., \& Graham, W. F. (1989). Toward a conceptual framework for mixed-method evaluation designs. Educational Evaluation and Policy Analysis, 11, 255-274. https://doi.org/10.3102/01623737011003255

Jick, T. D. (1979). Mixing qualitative and quantitative methods: Triangulation in action. Administrative Science Quarterly, 24, 602-611. https://doi.org/10.2307/2392366

Knapp, M. (1985). Audit Conflict: An Empirical Study of the Perceived Ability of Auditors to Resist Management Pressure, the Accounting Review, 60(2), 202-211. Retrieved July 25, 2018 from: http://www.jstor.org/stable/246786

Knapp, M. (1987). An Empirical Study of Audit Committee Support for Auditors Involved in Technical Disputes with Client Management, The Accounting Review, 62(3), 578-588, Retrieved July 25, 2018 from: https://www.jstor.org/stable/247578

Knechel, W. R., Krishnan, G. V., Pevzner, M., Shefchik, L. B., \& Velury, U. K. (2013). Audit Quality: Insights from the Academic Literature, Auditing: A Journal of Practice \& Theory, 32(1). https://doi.org/10.2308/ajpt-50350

Malina, M., Norreklit, H., \& Selto, F. (2011). Lessons learned advantages and disadvantages of mixed method research. Qualitative Research in Accounting \& Management, 8(1), 59-71. https://doi.org/10.1108/11766091111124702

Mason, R., Gunst, R., \& Hess, J. (2003). Statistical Design and Analysis of Experiments with Applications to Engineering and Science, 2nd Edition, John Wiley \& Sons.

Miko, N., \& Kamardin, H. (2015). Impact of Audit Committee and Audit Quality on Preventing Earnings Management in the Pre- and Post- Nigerian Corporate Governance Code 2011, Procedia-Social and Behavioral Sciences, 172(2015), 651-657. https://doi.org/10.1016/j.sbspro.2015.01.415

Montenegro, T. M., \& Brás, F. A. (2018). Review of the Concept and Measures of Audit Quality in Three Decades of Research. International Journal of Accounting, Auditing and Performance Evaluation, 14(2/3), 183-253. https://doi.org/10.1504/IJAAPE.2018.091063

$\mathrm{Ng}$, T. B., \& Tan, H. (2003). Effects of authoritative guidance availability and audit committee effectiveness on auditors' judgements in an auditor-client negotiation context. The Accounting Review, 78(3), 801818. https://doi.org/10.2308/bria-51259

Obaidat, A. (2007). Auditors compliance with international standards on auditing (ISAs): Evidence form Jordan, Journal of Social Sciences, 3(4), 185-189. https://doi.org/10.3844/jssp.2007.185.189

Park, B. (2018). Audit Committees and Managerial Influence on Audit Quality: 'Voluntary' versus 'Mandatory' Approach to Corporate Governance. Australian Accounting Review, O(0), 1-15. https://doi.org/10.1111/auar.12263

Piot, C., \& Janin, R. (2007). External Auditors, Audit Committees and Earnings Management in France, 
European Accounting Review, 16(2), 429-454. https://doi.org/10.1080/09638180701391030

Plastow, N. (2016). Mixing-up research methods: A recipe for success or disaster? South African Journal of Occupational Therapy, 46(1), 89-90. https://doi.org/10.17159/2310-3833/2016/v46n1a16

Salleh, Z., \& Stewart, J. (2012). The role of the audit committee in resolving auditor-client disagreements: a Malaysian study. Accounting, Auditing and Accountability Journal, 25(8), 1340-1372. https://doi.org/10.1108/09513571211275506

Sekaran, U. (2003). Research methods for business: A skill building approach. John Wiley \& Sons.

Saunders, M. N. K., Lewis, P., \& Thornhill, A. (2012). Research Methods for Business Students. (6/E). Financial Times Prent.Int. UK. Pearson Education.

Shbeilat, M. K. (2013). The Jordanian Corporate Governance Code: a Study of Institutional Investors' Perception of the Reliability of the Audit Report and the Audit Expectation Gap. Unpublished Doctoral thesis, The Australian catholic University Sydney, Australia. https://doi.org/10.4226/66/5a96308fc68a1

Shbeilat, M., \& Harasis, M. (2018). Do listed companies Need an IFRS Committee Beside Audit Committee? International Journal of Academic Research in Accounting, Finance and Management Sciences, 8(2), 8-18.

Shehata, N. (2015). Development of corporate governance codes in the GCC: An overview, Corporate Governance: The Journal of Business in Society, 15(3), 315-338.

Rahim, M. F. A., Johari, R. J., \& Takril, N. F. (2015). Revisited Note on Corporate Governance and Quality of Audit Committee: Malaysian Perspective. Procedia Economics and Finance, 28, 213-221. https://doi.org/10.1016/S2212-5671(15)01102-8

Securities Depository Center (2018). Jordanian Corporate Governance Code - Private Shareholding Companies, Limited Liability Companies \& Non Listed Public Shareholding Companies. Accessed on May 14, 2018, from: https://www.sdc.com.jo/english/images/stories/pdf/corporateguidee.pdf

Sertima, M. A. V. (2008). Statement on Auditing Standard 114: The Auditor's Communication With Those Charged With Governance, Benefits \& Compensation Digest, 45(9), 38-41. Retrieved, May 13, 2018 from http://connection.ebscohost.com/c/articles/34243938/statement-auditing-standard-114-auditors-communicat ion-those-charged-governance

Songini, L., \& Gnan, L. (2015). "Family involvement and agency cost control mechanisms in family small and medium-sized enterprises", Journal of Small Business Management, 53(3), 748-779. https://doi.org/10.1111/jsbm.12085

Stewart, J., \& Munro, L (2007). The Impact of Audit Committee Existence and Audit Committee Meeting Frequency on the External Audit: Perceptions of Australian Auditors, 11(1), 51-69. https://doi.org/10.1111/j.1099-1123.2007.00356.x

Suyono, E. (2012). Determinant Factors Affecting the Audit Quality: An Indonesian Perspective, Global Review of Accounting and Finance, 3(2), 42-57.

Tashakkori, A., \& Teddlie, C. (2010). SAGE Handbook of Mixed Methods in Social \& Behavioral Research. SAGE. https://doi.org/10.4135/9781506335193

Zgarni, I., Khmoussi H., \& Zehri, F. (2016) Effective audit committee, audit quality and earnings management: Evidence from Tunisia, Journal of Accounting in Emerging Economies, 6(2), 138-155. https://doi.org/10.1108/JAEE-09-2013-0048

\section{Copyrights}

Copyright for this article is retained by the author(s), with first publication rights granted to the journal.

This is an open-access article distributed under the terms and conditions of the Creative Commons Attribution license (http://creativecommons.org/licenses/by/4.0/). 